\title{
The Changing Geomorphology of Danubian Floodplains in Hungary ${ }^{1}$
}

\author{
Dénes Lóczy
}

The once extensive floodplains along the Hungarian section of the Danube have mostly disappeared by now or have been restricted to certain reaches of the river: the Szigetköz alluvial fan, minor remnants in the environs of Budapest and the Gemenc Forest and Béda-Karapancsa area along the southernmost Hungarian section studied here (continued on Croatian territory). From ancient times floodplains have supplied valuable economic resources and, consequently, have undergone major transformations. They are now mostly under cultivation or environmental protection. In the paper their natural and man-influenced evolution is outlined with an evaluation of perspectives for rehabilitation. Floodplain topography is evaluated and mapped for features of natural and man-made origin as well for present-day functioning in the landscape. In compliance with EU directives intensive farming is envisaged to cease over large areas of lower productivity beyond flood-control dykes and these areas will be available for rehabilitation serving conservation (through landform and habitat restoration) and flood control (through floodwater storage). Locally, traditional floodplain economy (fishing, grazing, vegetable gardens and orchards) is being restored.

Keywords: Dunav, Hungary, floodplain, landforms, land use, human pressure

\section{Geomorfološke promjene naplavne ravnice Dunava u Mađarskoj}

Nekad prostrane naplavne ravnice Dunava u Mađarskoj dosad su većinom nestale ili su ograničene na neke dijelove rijeke: fluvijalna plavina Szigetköz, manji ostaci u okolici Budimpešte te u području šume Gemenc i Béda-Karapancsa duž najjužnijeg dijela u Mađarskoj koji se nastavlja i na teritorij Hrvatske. Naplavne ravnice od davnina predstavljaju vrijedne gospodarske resurse te su upravo stoga i doživjele veliku transformaciju. Danas su uglavnom obrađene i ekološki zaštićene. U ovom je radu dat njihov prirodni razvitak kao i onaj pod utjecajem čovjeka, a vrednovana je i mogućnost njihovog ponovnog oživljavanja. Vrednovana je, dakle, i kartirana fluvijalna topografija naplavne ravnice tj. prirodno i antropogeno preoblikovani oblici kao i današnje funkcioniranje krajolika. EU predlaže da se dosadašnja ekstenzivna antropogena valorizacija, unutar nasipa kontroliranog plavnog područja, smanji ili prekine, te da se ponovo stimulira odgovarajući razvoj prirodnog okoliša. To znači da bi se eksperimentalno, mjestimice, ponovo oživilo tradicionalno gospodarstvo naplavne ravnice (ribolov, ispaša, povrtlarstvo i voćarstvo).

Ključne riječi: Dunav, Mađarska, naplavna ravnica, reljefni oblici, iskorištavanje zemljišta, antropogeni utjecaj 


\section{INTRODUCTION}

In the temperate belt floods are natural events in the life of rivers. Their more or less predictable return periods result in accelerated landform evolution and improved or even extremely superfluous water supply in the floodplain, while their absence often leads to drought severely affecting ecosystems. In a modern concept, floodplains constitute an integral part of the fluvial system in the same way as river channels are (Baker, V.R. et al. 1988). The hydraulic laws of floodplain evolution (Anderson, M.G., Walling, D.E. and Bates, P.D. 1996) are similar to those of channels but some differences are obvious:

- the fluvial processes of floodplain development are interrupted and restricted to flood stages;

- during flooding streamwater flows through a much wider cross-section of altered shape;

- the spatial pattern of currents is much more complicated than that of channel flow and secondary flows can only be investigated properly in three dimensions (Knight, D.W. - Shiono, K. 1996).

Geomorphological patterns in floodplains influence the spatial distribution of ecosystems and human land use. At the same time, human pressure in the form of water management and shipping structures, recreation facilities, access roads etc. modifies landform patterns (Graf, W.L. 1996). Recently, floods along the Danube (Fig. 1) have acquired a rather extraordinary temporal pattern: the highest water levels were recorded in months (December and August) when the lowest ones are the rule. The low predictability of geomorphic events also presents a major obstacle in the way of reckoning with the impacts of planned river restoration measures.

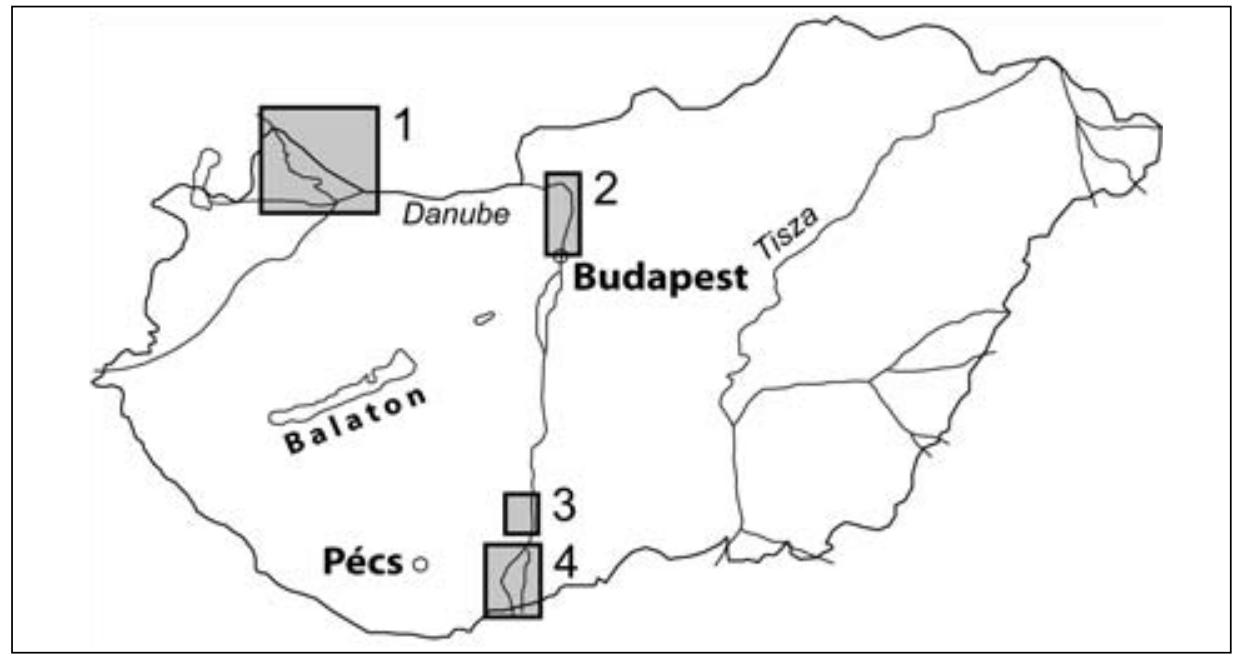

Fig. 1 The seminatural floodplain sections of the Hungarian Danube reaches studied 1 = the Szigetköz alluvial fan; 2 = islands in the Budapest area; 3 = Gemenc Forest; 4 = the floodplain S of Mohács

Sl. 1. Poluprirodni dijelovi naplavne ravnice mađarskog dijela Dunava

1 = fluvijlana plavina Szigetköz; 2 = otoci u području Budimpešte; 3 = šuma Gemenc; 4 = naplavna ravan južno od Mohača 


\section{A BRIEF EVOLUTION HISTORY OF THE HUNGARIAN DANUBE SECTION}

In Hungarian geomorphology as well as geology research into the evolution of the drainage network in the Carpathian Basin has been intensive from the very beginning. It suffices to mention here the names of Lajos Lóczy Sen., Jenö Cholnoky, József Sümeghy, Béla Bulla, Márton Pécsi and Sándor Somogyi, who all came forth with their own views on the history of drainage conditions during Pliocene-Pleistocene-Holocene times. The changes in the courses of both of the main axes of drainage, the Danube and the Tisza, have presented serious problems to solve. Nowadays, particularly the Danube and its tributaries provoke confronting opinions from the various researchers (Lóczy, D. 2007). The most recent drainage reconstruction (Borsy, Z. 1990) claims that the Danube had not occupied its present-day lowland channel across the western margin of the steadily subsiding Great Hungarian Plain until the beginning of the Upper Pleniglacial (ca $29 \mathrm{ka}$ BP; Fig. 2). The accumulation of the older fluvial sequence preceding the arrival of the Danube is attributed to another river, the Ancient Sárvíz, on the basis of sedimentological evidence (shorter transport distance of sand inferred from the common occurrence of splintery grains - Borsy, Z. 1990).

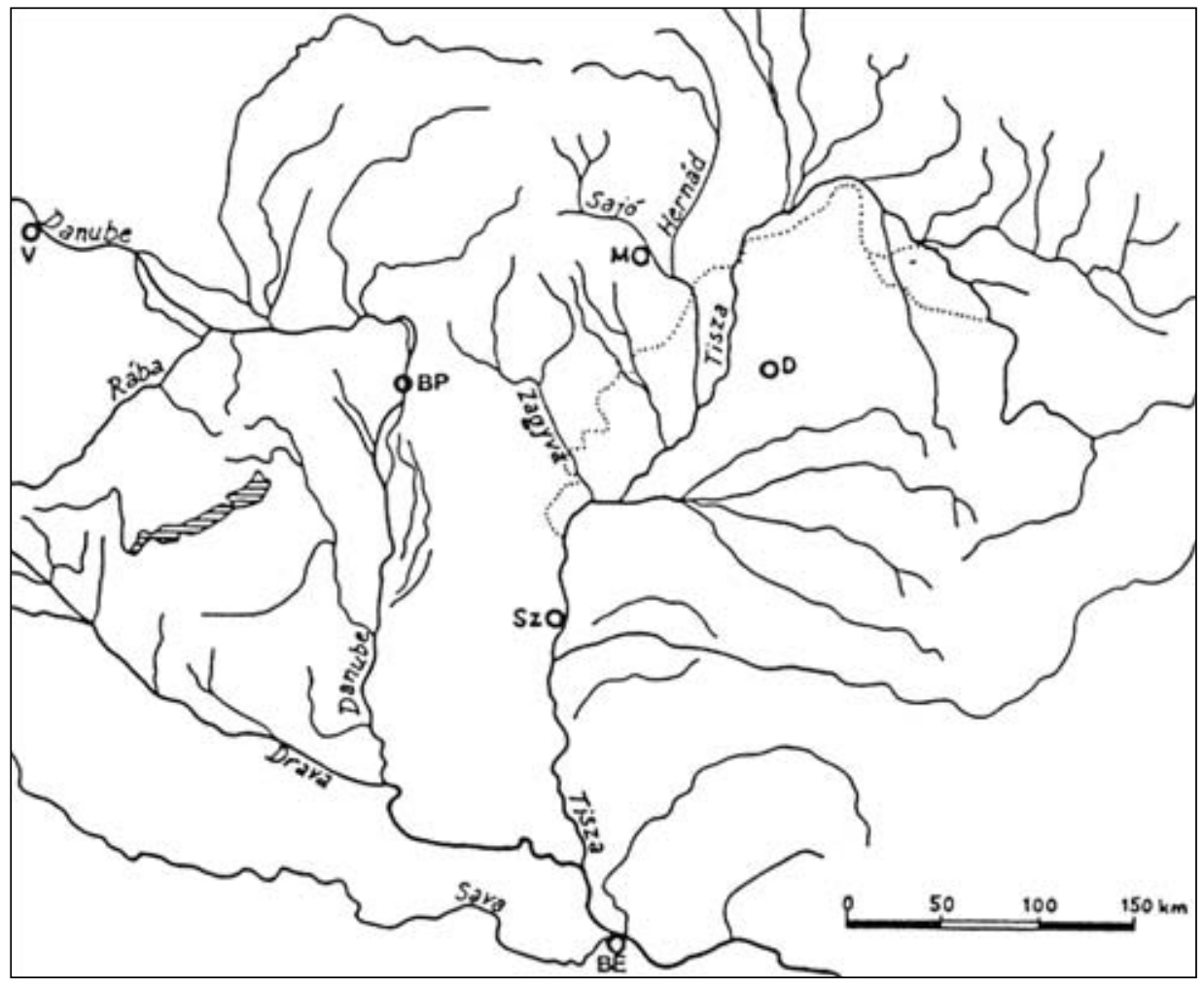

Fig. 2 Reconstruction of the drainage network of the Carpathian Basin for the Upper Pleniglacial (after Borsy Z. 1990)

Sl. 2. Rekonstrukcija dolinske mreže u Karpatskom bazenu u gornjem pleniglacijalu (prema Borsy Z., 1990) 
The survival of elevations mantled by gravel in the eastern neighbourhood of the present-day Danube channel attest to a braided river mechanism during glaciations (Pécsi, M. 1959). Meandering only became a prevailing mechanism for most of the studied section in post-glacial times when massive infilling compensated for the gradual subsidence of the area and channel slope was reduced (Somogyi, S. 1979). A reconstruction of the course of the main Danube channel prior to flow regulation measures (Fig. 3, Tab. 1) clearly reflects an intricate pattern of meandering. A study based on the interpretation of historical maps revealed that, under the recent flow regime, it takes ca. 150 years for a meander to develop from a section of $S=1.5$ sinuosity to cutoff completed (Somogyi, S. 1974).

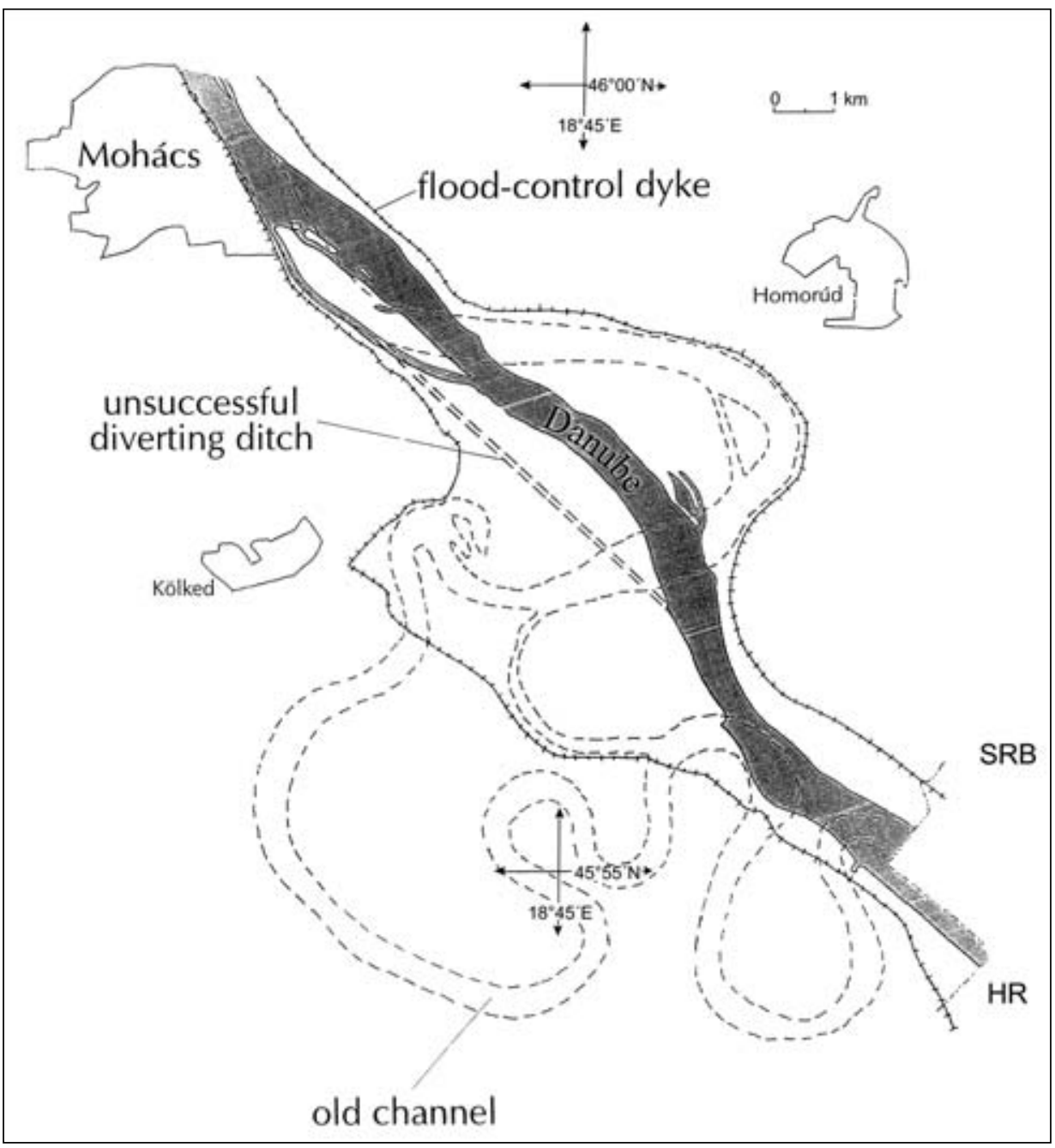

Fig. 3 Reconstruction of the meandering Danube channel before regulation S of Mohács (Lóczy, D. 2001) Sl. 3. Rekonstrukcija menadrskih korita Dunava prije regulacije južno od Mohača (Lóczy, D. 2001.) 
Tab. 1 Morphometric indices for the reconstructed old Danube channel south of Mohács (Lóczy, D.)

- " indicates values not acceptable for natural meanders

Tab. 1. Morfometrijska obilježja obnovljenog starog dunavskog korita južno od Mohača (Lóczy, D.) - "označava vrijednosti koje nisu prihvatljive za prirodne meandre

\begin{tabular}{|c|c|c|c|c|c|}
\hline $\begin{array}{c}\text { number of river } \\
\text { section (meander) }\end{array}$ & $\begin{array}{c}\text { sinuosity } \\
(\mathrm{S})\end{array}$ & $\begin{array}{c}\text { bend radius } \\
(\mathrm{r}, \text { metres) }\end{array}$ & $\begin{array}{c}\text { channel } \\
\text { width (w, metres) }\end{array}$ & r/w & $\begin{array}{c}\text { angle of direction change } \\
\text { between inflection points }\left(\Delta \alpha,^{\circ}\right)\end{array}$ \\
\hline 1 & 2.26 & 1250 & 400 & 3.1 & 164 \\
\hline 2 & 2.14 & 1000 & 150 & $6.7^{*}$ & 151 \\
\hline 3 & 3.09 & 400 & 300 & $1.3^{*}$ & 198 \\
\hline 4 & 1.23 & 750 & 300 & 2.5 & 115 \\
\hline 5 & 1.17 & 1100 & 350 & 3.1 & 129 \\
\hline 6 & 1.07 & 2800 & 300 & $9.3^{*}$ & 176 \\
\hline 7 & 1.78 & 780 & 300 & 2.6 & 258 \\
\hline 8 & 4.44 & 650 & 300 & 2.7 & 163 \\
\hline 9 & 2.34 & 560 & 250 & 2.2 & 258 \\
\hline 10 & 3.13 & 750 & 400 & 1.9 & 257 \\
\hline 11 & 3.75 & 1100 & 300 & 3.7 & \\
\hline
\end{tabular}

A typical convex floodplain has evolved, similar to the one found along the Missouri ('Science for Floodplain Management...' 2000 - Fig. 4). A study of floodplain sediment sequences suggests that within this interval accretional meander systems usually produced

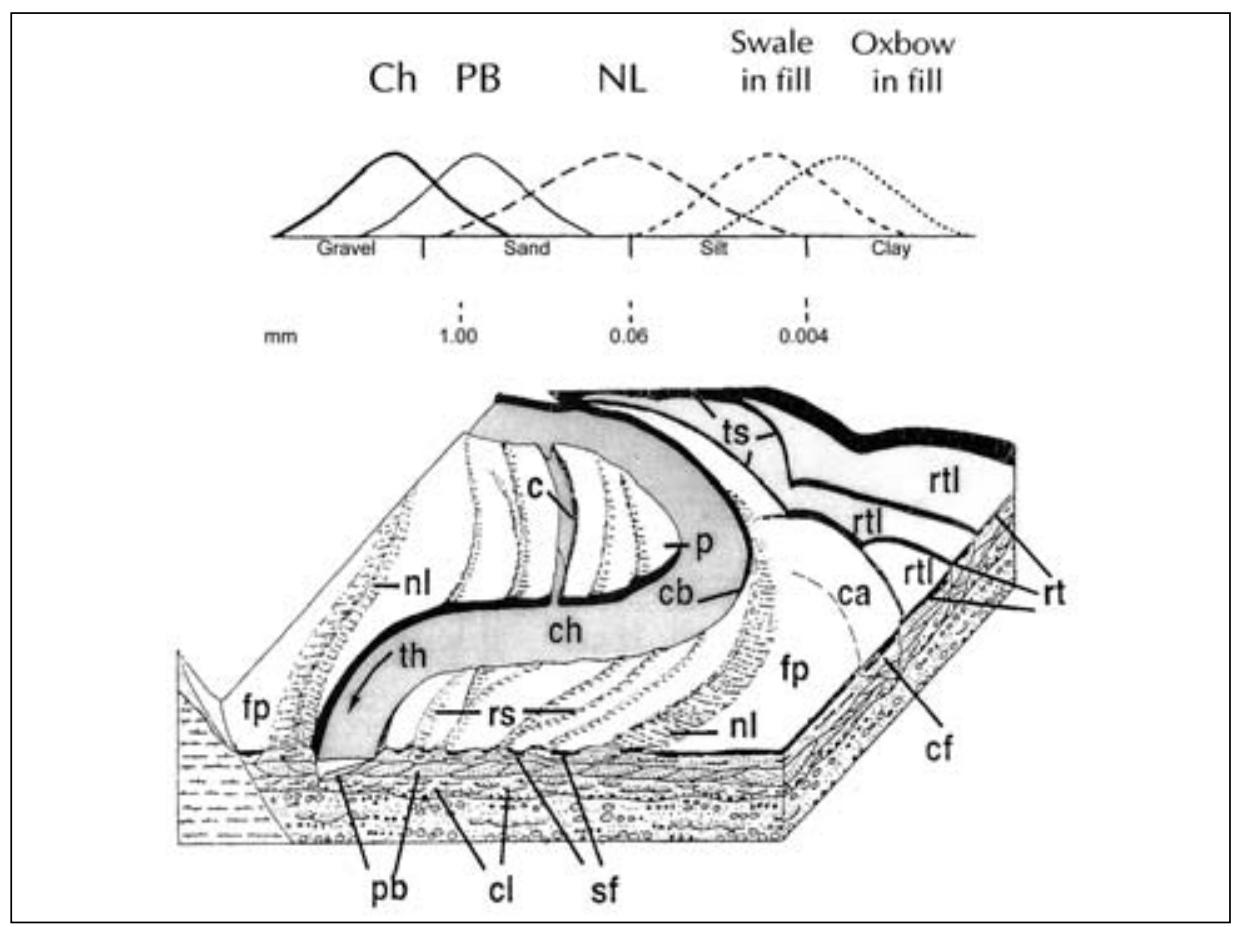

Fig. 4 Block diagram of a typical convex floodplain with typical landforms (after Allen, J.R.L. 1985 and an illustration in the document 'Science for Floodplain Management ...' 2000)

Sl. 4. Blok dijagram tipične konveksne naplavne ravnice s tipičnim oblicima reljefa (prema Allenu, J. R. L., 1985 i ilustraciji u dokumentu "Science for Floodplain Management...", 2000.) 


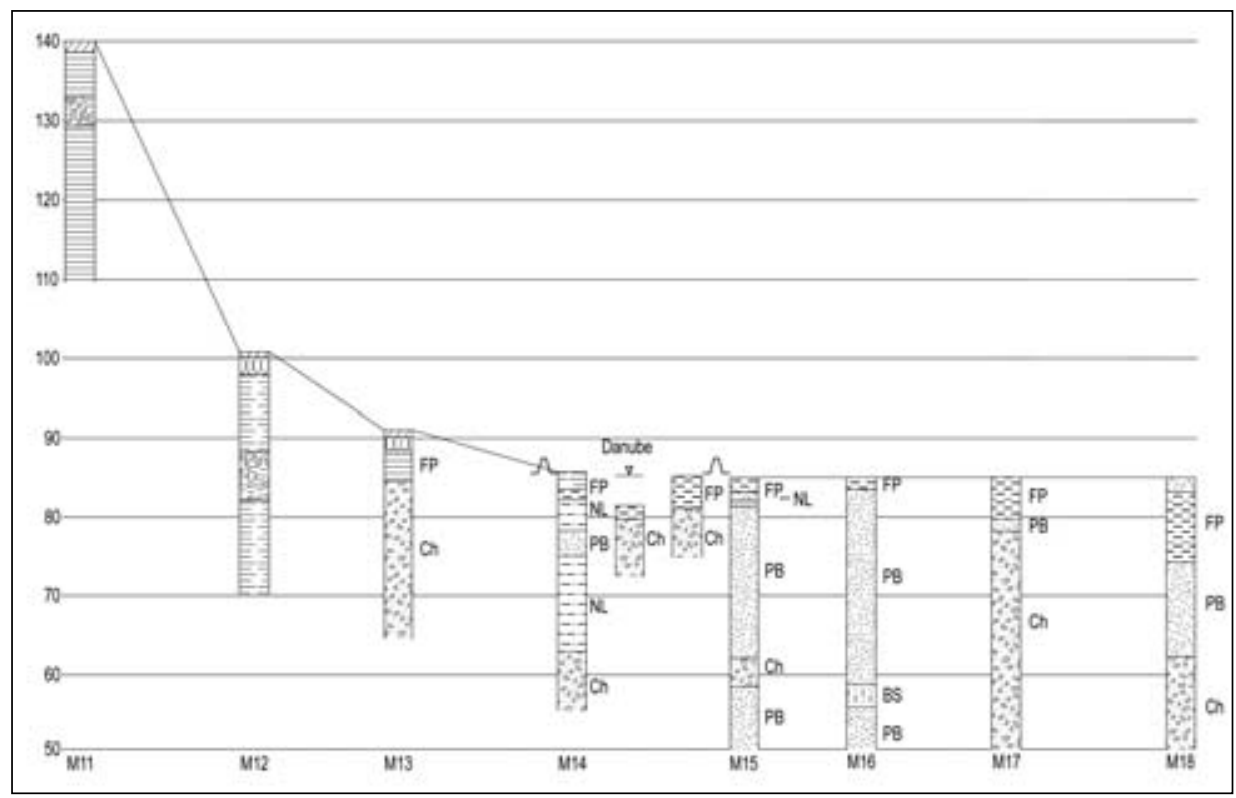

Fig. 5 Fluvial sediment sequences from the lowermost Danube section in Hungary (based on data of shallow boreholes from the Hungarian Geological Survey, 1991)

Sl. 5. Profili fluvijalnih naslaga s prostora najjužnije sekcije Dunava i njegove naplavne ravnice u Mađarskoj (temeljeno na podacima plitkih bušotina Mađarskog geološkog Instituta, 1991.)

point-bar accumulations of 15-25 $\mathrm{m}$ depth interrupted by channel bed or floodplain deposits (Fig. 5). The present-day geomorphological pattern is fundamentally a reflection of this most recent natural sedimentological system, to which human influences were added (Hooke, J. M. 1987).

Flow regulation measures began to be implemented along the larger rivers of Hungary from the late $18^{\text {th }}$ century and this intervention intensified in the second half of the $19^{\text {th }}$ century (Ihrig, D. 1973; Erdösi, F. 1977). The active floodplain became substantially narrower and stream velocity increased in the wake of cutoffs. Increased floodplain siltation resulted in higher flood levels, while low-water levels dropped because of channel incision. The grain size distribution of sediment transported was altered by the construction of dams in Austria.

\section{FLOODPLAIN ECONOMY BASED ON 'NOTCHES'}

Let us look back to times much before the flow regulation measures were implemented. The traditional human utilisation of Danubian floodplains took the form of exploiting 'notch' systems (Andrásfalvy, B. 1973, 1976). According to the ethnographer Andrásfalvy's (1973) definition, a 'notch' (in Hungarian: fok) is 'a man-made ditch cutting through natural levees and during high stages allowing water flow out over the entire floodplain and during recession back to the channel' (Fig. 6). The system dates back to the $13^{\text {th }}$ century at 


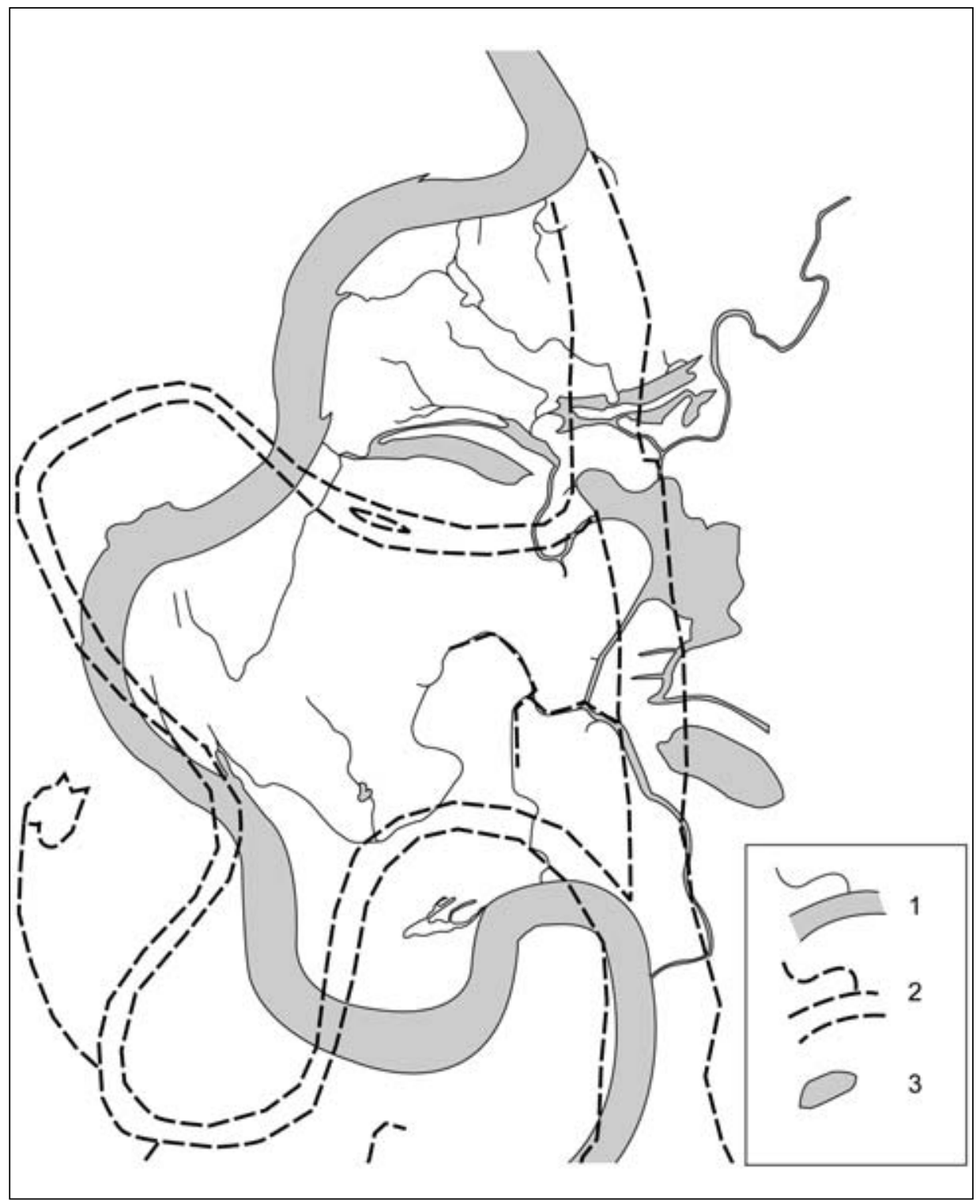

Fig. 6 Typical 'notch' system along the Danube in the Gemenc Forest, $5 \mathrm{~km}$ north of the town of Baja (rectangle 3 in Fig. 1)

$1=$ Danube channel and traces of 'notches' in 1950;

2 = Danube channel and 'notches' in 1820 (source: Episcopal Archive, Kalocsa, map code KÉGL.T. 97);

$3=$ backswamps and lakes

Sl. 6. Tipični kanalski sustav antropogenog podrijetla izmađu Dunava i šume Gemenc, 5 km sjeverno odgrada Baja (pravokutnik 3 u Sl. 1)

$1=$ Korita Dunava i tragovi antropogenih kanala (fokova) iz 1950;

2 = Korito Dunava i antropogeni kanali iz 1820 (izvor: Episcopal Archive, Kalocsa, šifra karte KÉGL.T.97);

3 = močvare i jezera u naplavnoj ravnici 


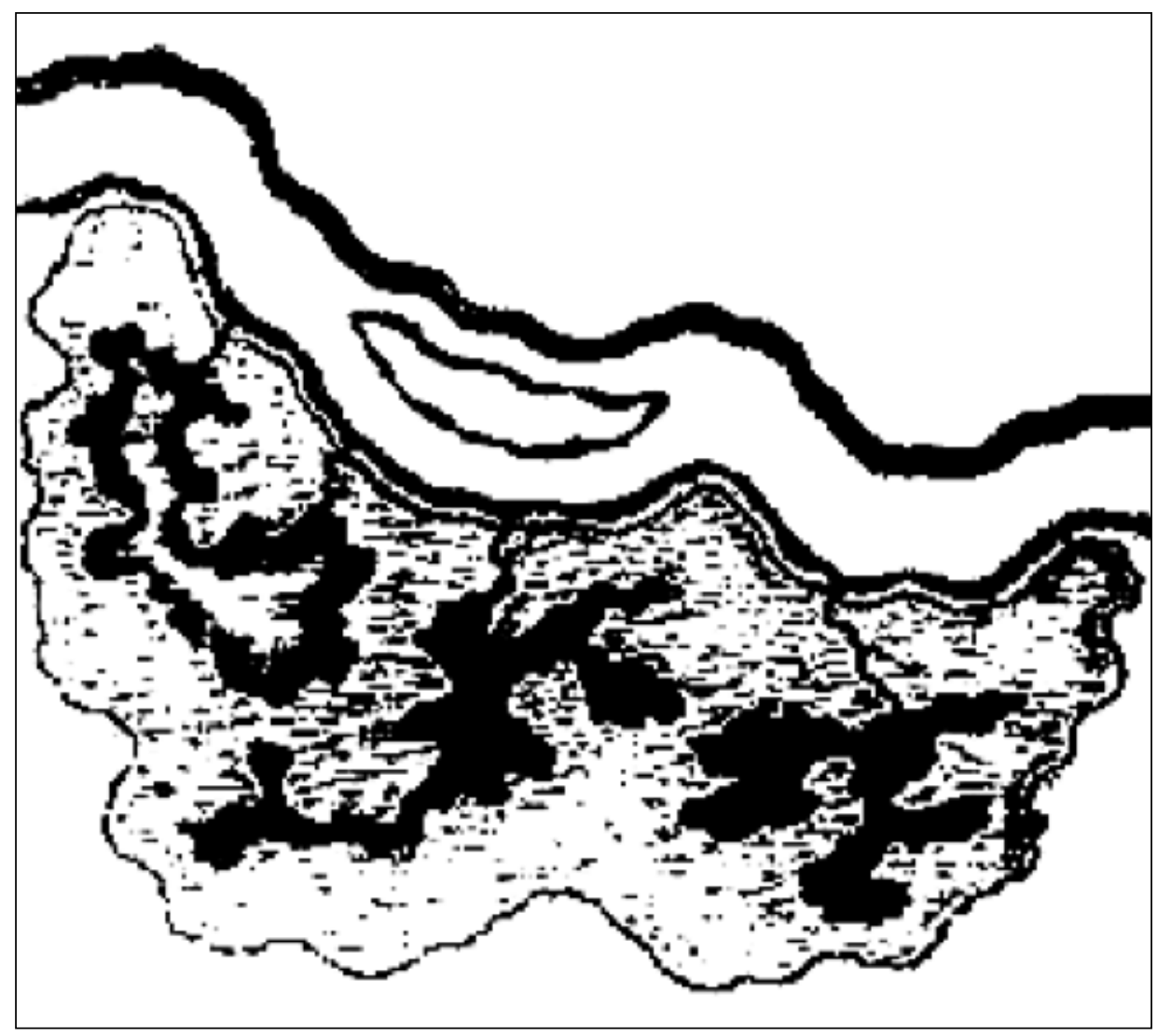

Fig. 7 'Notches' as they appear on Marsigli's map of the Danube (1726)

Sl. 7. Antropogeni kanali kaji se pojavljuju na Marsiglijevoj karti Dunava iz 1726. godine

least and functioned successfully up to the Ottoman Occupation (16-17 ${ }^{\text {th }}$ centuries), when notches became neglected. However, their remnants are still described by L. F. Marsigli (1726) in his detailed description and map series of the Danube (Fig. 7). Primary channels lead floodwater to the plain and a network of secondary ones link oxbows, meander swales and backswamps to them in order to ensure water storage (Andrásfalvy B. 1973) and prevent the seasonal desiccation of the floodplain.

The traditional floodplain economy had a range of advantages for the local population (Andrásfalvy B. 1973):

1. At flooding water left the channel in a tranquil flow and spread over the floodplain almost uniformly. Devastation by flood waves could be avoided.

2. During high water stages and well after the flood began to recede, water could be stored in the floodplain. When it was no longer needed, it could be conducted through the notches gradually back into the main channel. The damage by stagnant water of deteriorating quality on vegetation and fish stock could be eliminated. 
3. Flooding of floodplain section created spawning grounds with optimal depth of inundation. Thus the reproduction of fish stocks was ensured. Fishing in the notches provided protein-rich nutrition even in times of food shortage.

4. An immediate economic use is manifested in keeping meadows well-watered all the year round for mowing and grazing and in increasing the fertility of alluvial soils by the deposition of nutrient-rich mud. Vegetable gardens and orchards could be established in the floodplain.

5. The artificial canals between oxbows, swales and backswamps also functioned as waterways in otherwise inaccessible areas.

Eventually, flow regulation measures put an end to this traditional floodplain economy, since before raising flood control dykes notches had to be filled up. River incision and gradual siltation made the still existing ditches incapable to fulfill their functions.

\section{DISTINGUISHING BETWEEN NATURAL AND MAN-MADE LANDFORMS IN THE FLOODPLAIN}

To date notches have been studied mostly from ethnographical (anthropological) and paleoecological and increasingly from water management aspects (Karácsonyi, Z. 2001), while their geomorphology has been largely neglected. To a geomorphologist the question emerges: to what extent are the notches, the pattern of which maintained this system of traditional floodplain economy, related to natural landforms? Evidence shows that the routing of notches was selected with a profound knowledge of natural drainage conditions. For instance, they are often designed to have a meandering course to slow down water flow and thus prevent large-scale erosion. They may have consciously selected gaps at downstream sections of meander scrolls as ditch entrances. It is presumed that our ancestors used an instinctive knowledge of geomorphology when digging the ditches - even more successfully than the engineers of $19^{\text {th }}$-century flow regulation.

Natural levees are never perfectly continuous. Their gaps arise from various causes (Allen, J. R. L. 1985). They may be related to large-scale vortices (reviewed by Knight, D. W. and Shiono, K. 1996) comparable in diameter to river widths, which form as secondary flows during the peak stages of flooding. The existence of these Kelvin-Helmholtz-type vortices of vertical axis (Fig. 8) has also been confirmed by areal photography and laboratory experiments (Sellin, R. H. J. 1964). Vortices of this kind alternately occurring on both banks of the river channel transfer impulse from the channel of greater water depth to the floodplain under shallow inundation. The physical explanation of their origin exploits the shear stress generated between the much more rapid channel flow (Simons, D. B. 1969) and the slower flow in the floodplain (Anderson, M. G. et al. 1996).

The assumption that overbank vortices may play a part in geomorphic evolution is supported by observations of slope conditions within a single meander loop. Natural levees along the upstream sections of meanders often rise higher above the river water level (like it has been pointed out from the Missouri floodplain). This leads to locally quite remarkable slopes, certainly exceeding channel floor gradients. In the case of the studied 


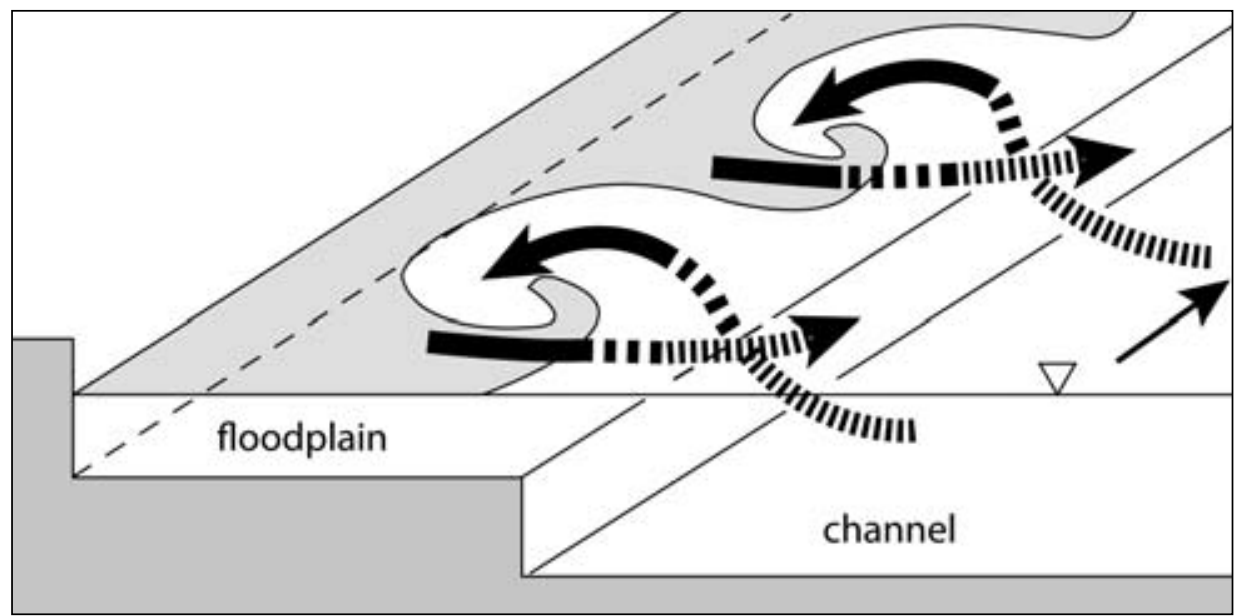

Fig. 8 A schematic representation of large vortices of vertical axis in flooding rivers (after Knight, D. W. \& Shiono, K. 1996)

Sl. 8. Shematski prikaz velikih okomitih virova u nabujalim rijekama (prema Knightu, D. W. \& Shiono, K. 1996.)

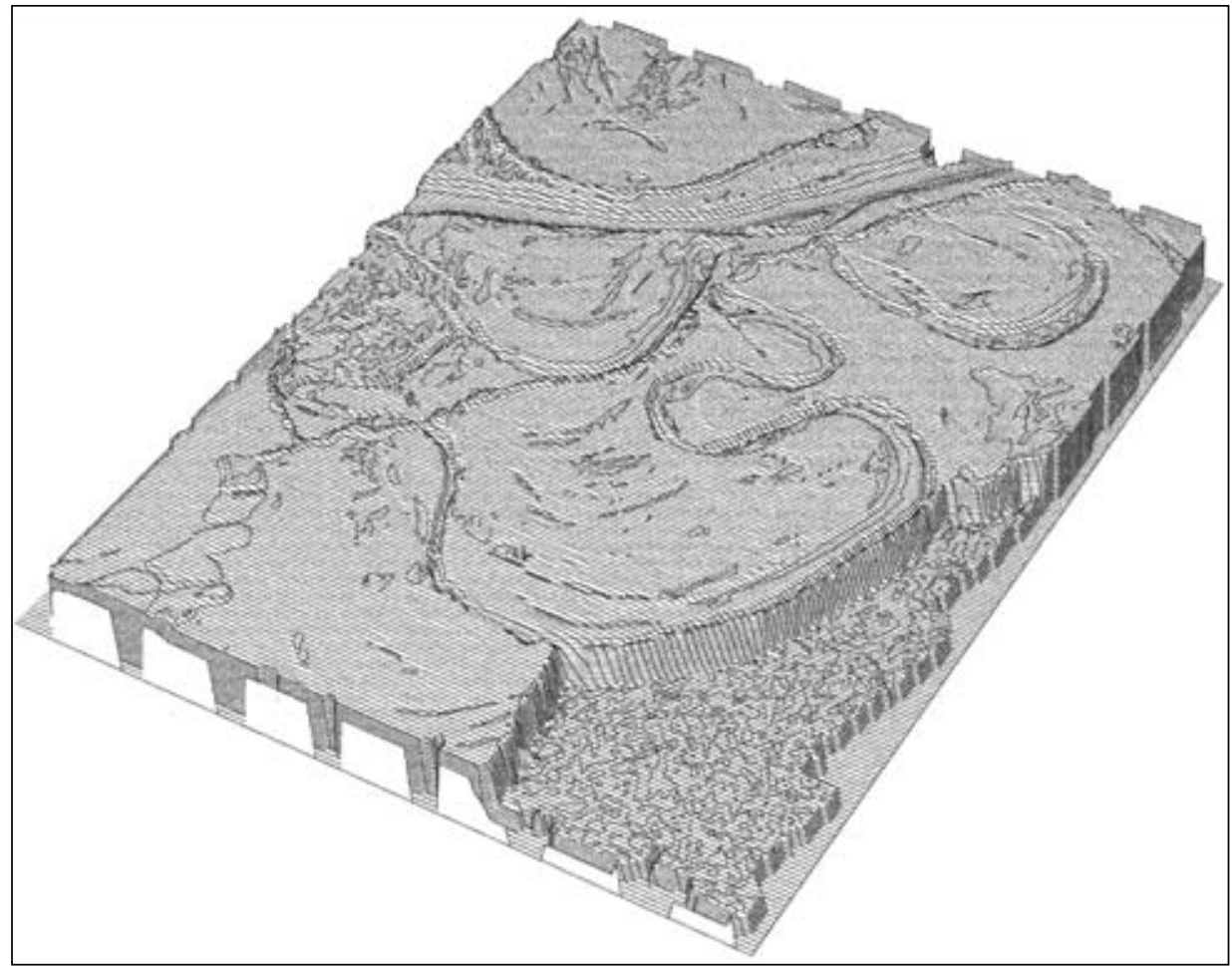

Fig. 9 Digital elevation model of an old meander of the Danube S of Mohács (by Milics, G.)

Sl. 9. Digitalni model reljefa starog meandra Dunava južno od Mohača 
section of the old Danube, this asymmetry occasionally reaches the extent of ca 25 per cent, ie. $4 \mathrm{~m}$ as opposed to $3 \mathrm{~m}$ along the lower reaches of the same meander (Fig. 9). Also the coarsest floodplain sedimentation occurs along the crests of these levees. With an approaching flood wave, water level rise usually exceeds levee tops first at the lower third of the meander course and it might be the site of vortex generation too. As a function of river sinuousity, the centre of the eddy leaves the course prescribed by the bank and intrudes into the swales of the meander scroll. This erosional process may lead to the formation of an embryonic chute, which begins to retreat in upvalley direction across the floodplain. Flow will later follow the steepest-gradient route across the meander scroll and eventually a chute cutoff may result. Although not so well studied as neck cutoffs, chute cutoffs may have contributed much more significantly to the evolution of the Danube channel as it was thought before.

An observation from the Russian Plain (Popov, I.V. and Gavrin, Yu.S. 1970) also seems to support the assumption related to the location of levee breaches. Investigating floods on the River Oka in April 1968, they found that meander swales were first flooded below a bend in opposite direction to channel flow and only subsequently were the upstream sections of natural levees breached and flow started downvalley across the entire floodplain.

Thus, indirect evidence suggests that our ancestors took advantage of the gaps across levees in order to construct networks of notches for the purposes of the economic exploitation of floodplains. The idea was to conduct water into oxbows and backswamps through the swales between bars but in an upstream direction. The meandering planform of the artificial ditches ensured gradual water supply with a minimum hazard of erosion. A mapping project aims at surveying natural and human-influenced landforms along the southernmost Hungarian section of the Danube. The temporary results, however, do not support the view that the majority of notches conducted water 'from below', against the general slope of the floodplain.

\section{GEOMORPHOLOGY AND DISTRIBUTION PATTERNS OF POLLUTION LOAD}

Similarly to sediment transport, the deposition of pollutants in floodplains, in general, has a beneficial impact on river water quality. The efficiency of this kind of water purification heavily depends on river mechanism as a primary control which governs the grain size and pattern of deposition, channel and floodplain morphology, type of floodplain vegetation and a range of other properties of the floodplain ecosystem. Naturally, floodplains can only fulfill their water purification function if they are closely integrated to the main river channel. In extreme cases (like the Slovak-Hungarian barrage construction - Erdélyi, M. 1994), diversions may almost completely isolate floodplain channels from the main channel (Tab. 2). 
Tab. 2 Changes in annual average water availability on the Szigetköz floodplain (along the Hungarian section of the Danube) immediately before and after the construction of the Gabčikovo Barrage (Lóczy, D. from various sources)

Tab. 2. Promjene prosječne godišnje količine vode u naplavnoj ravnici Szigetköz (duž mađarskog dijela Dunava) odmah prije i poslije izgradnje Gabčikovo Barrage (Lóczy, D. iz različitih izvora)

\begin{tabular}{|c|c|c|}
\hline $\begin{array}{c}\text { linkage of by-channels to } \\
\text { main channel }\end{array}$ & $\begin{array}{c}\text { number of days in a year before } \\
\text { barrage construction }\end{array}$ & after \\
\hline direct communication & 200 & 5 \\
\hline $\begin{array}{c}\text { subsurface seepage but no } \\
\text { channel flow }\end{array}$ & 100 & - \\
\hline low in by-channels & 90 & - \\
\hline inundation of floodplain & 10 & \\
\hline
\end{tabular}

The distribution of pollution load in active floodplains is essentially controlled by microtopography and the related vegetation pattern. In Danubian floodplain forests it was found that vegetation strongly influences the filtering capacity for dispersed pollutants (Szalai, Z. 1998), mainly through specific surface area of the shrub, liana and herbaceous horizons. Too dense a vegetation (e.g. a seminatural shrub with improper maintenance), on the other hand, may inhibit the passage of flood waves and, therefore, it is not regarded a positive phenomenon by those responsible for water management.

\section{PERSPECTIVES FOR FLOODPLAIN REHABILITATION}

Why is there a need for floodplain rehabilitation? Flow regulation measures reduced the capability of floodplains to fulfill their various ecological functions (Dynesius, M. and Nilsson, C. 1994; Zsuffa, I. and László, B. 1998). There is a qualitative and a quantitative side of rehabilitation, ie. minimum interlinkages of ecosystems of improved biodiversity and filtering capacity as well as minimum sustainable sizes of ecotopes have to be established.

Although technically feasible, the restoration of old Danube meanders as active channels would be too cost-intensive. Similarly, a revival of traditional floodplain management is financially and socially unrealistic nowadays (for conservation and education some notches are being restored now.) However, a certain extent of floodplain restoration seems to be inevitable for several purposes. With rising flood levels, flood control is becoming an ever more serious task. Water management experts have recognised that floodplains have to be made capable to store floodwater more efficiently. In unmanaged floodplain forests, however, the overgrowth (like winter grapes) has reached a degree that it even hinders the passing of flood waves. A partial restoration of notches (even beyond the limits of the present-day active floodplain - Zsuffa, I. and László, B. 1998) could help to store more floodwater. Another requirement to meet is a satisfactory water supply of floodplain ecosystems, often including rare and protected plants. The survey of natural and man-made landforms provides assistance for the design of floodplain rehabilitation measures. 
It should to be emphasised too that floodplains also have an important role to play in water and air purification through accumulating pollutants. Most of the organic water pollutants decompose in floodplains. Industrial, agricultural and municipal wastewater, however, also contains a range of inorganic pollutants, which remain buried in the soils and sediments of the floodplain for centuries. Through a more precise quantification the constants required for the mentioned formulas could be applied successfully in floodplain management.

The southern section of the Danubian floodplain (Erdősi, F. \& Lehmann, A. 1974) in Hungary forms part of the Danube-Drava National Park, which has nature conservation, touristic and educational functions. In accordance with the modern concept of biological conservation, species should be preserved in their habitats. The restoration of habitats also involves the improvement of geomorphological conditions for ecosystem functioning. The resulting better water availability would produce a green landscape in the floodplains, also attractive for visitors.

\section{REFERENCES}

Allen J. R. L., 1985: Principles of Physical Sedimentology, Reprinted in 2001: Blackburn Press, Caldwell, NJ., $272 \mathrm{p}$.

Anderson M. G., Walling D.E. and Bates P.D. (eds.) 1996. Floodplain processes, John Wiley, New York, $658 \mathrm{p}$.

Andrásfalvy B., 1973: A Sárköz és a környező Duna-menti területek ösi ártéri gazdálkodása és vízhasználata a szabályozás elött (Ancient floodplain economy and water use in the Sárköz and along the Danube before flow regulation), VíZDOK, Budapest, 75 p. (Papers in Water Management History)

Andrásfalvy B., 1976: Duna-mente népének ártéri gazdálkodása Tolna és Baranya megyében a vízrendezés befejezéséig (Floodplain economy along the Danube in Tolna and Baranya counties until the end of flow regulation measures), Tolna County Museum, Szekszárd, 476 p. (Papers on the history of Tolna county VII.)

Baker V. B., Kochel R.C. and Patton P.C. (eds.) 1988: Flood Geomorphology, John Wiley, New York

Borsy Z., 1990: Evolution of the alluvial fan of the Alföld, in Rachocki A.H. and Church M. (eds.): Alluvial Fans: A Field Approach, John Wiley, Chichester, 229-248

Dynesius M. and Nilsson C., 1994: Fragmentation and flow regulation of river systems in the northern third of the World, Science, 266, 753-762

Erdélyi M., 1994: Hydrogeology of the Hungarian upper Danube section, Hungarian Natural History Museum, Budapest, $115 \mathrm{p}$.

Erdősi F., 1977: A társadalmi hatások értékelése a délkelet-dunántúli vizek példáján (An evaluation of human intervention into the waters of Southeast-Transdanubia), Földrajzi Értesítő, 26, 3-4, 305-336

Erdősi F. and Lehmann A., 1974: Mohács földrajza (A geography of the town Mohács), Mohács Town Council, Mohács, 501 p. + appendices

Graf W. L., 1996: Geomorphology and policy for restoration of impounded American rivers: What is 'natural?', in Rhoads B.L. and Thorn C.E. (eds.): The Scientific Nature of Geomorphology: Proceedings of the 27th Binghampton Symposium in Geomorphology, 27-29 September, 1996, John Wiley, New York, 443-473 
Hooke J. M., 1987: Changes in meander morphology, in Gardiner V. (ed.): International Geomorphology, 1986, Part I., John Wiley, Chichester, 591-609

Ihrig D., (ed.) 1973: A magyar vízszabályozás története (A history of flow regulation in Hungary), VÍZDOK, Budapest, $398 \mathrm{p}$.

Karácsonyi Z., 2001: Rehabilitation of the 'notch' system as tool for multipurpose floodplain management on the Upper Tisza river, in Nijland H.J. and Cals M.J.R. (eds.): River Restoration in Europe: Practical Approaches. Institute for Inland Water Management and Waste Water Treatment/RIZA, Lelystad, The Netherlands, 119-123 (RIZA Rapport no. 2001.023)

Knight D. W. and Shiono K., 1996: River Channel and Floodplain Hydraulics, in Anderson M.G., Walling D.E. and Bates P.D. (eds.): Floodplain Processes, John Wiley, Chichester, 139-181

Lóczy D., 2001: Geomorfológiai, tájökológiai és természetvédelmi megfigyelések a Duna-ártér Mohács alatti (bédai) szakaszán (Geomorphological, landscape ecological and nature conservation observation in the Hungarian Danube floodplain south of Mohács), A Magyar Földrajzi Konferencia 2001 előadásai, Szeged, 9 p. (CD)

Lóczy D., 2007: The Danube: Morphology, Evolution and Environmental Issues, in Gupta A. (ed.) Large Rivers, John Wiley and Sons, Chichester, 235-260

Marsigli L. F., 1726: Danubius panonico-misycus, Vols. I-VI, Amsterdam

Pécsi M., 1959: A magyarországi Duna-völgy kialakulása és felszínalaktana (Evolution and geomorphology of the Hungarian Danube valley), Akadémiai Kiadó, Budapest, 346 p.

Popov I. V. and Gavrin Yu. S., 1970: Use of aerial photography in evaluating the flooding and emptying of river flood plains and the development of flood-plain currents, Soviet Hydrology: Selected papers, 5, 413-425

Science for Floodplain Management into the 21st Century, 2000: Preliminary Report of the Scientific Assessment and Strategy Team, Report of the Interagency Floodplain Management Review Committee to the Administration Floodplain Management Task Force, A Blueprint for Change Part V.

Sellin R. H. J. 1964: A laboratory investigation in the interaction between flow in the channel of a river and that of its floodplain, La Houille Blanche, No. 7, 793-801

Simons D. B., 1969: Open channel flow, in Chorley R.J. (ed.): Water, Man and Earth. Methuen, London, 297-318

Somogyi S., 1974: Meder- és ártérfejlődés a Duna sárközi szakaszán az 1782-1950 közötti felvételek tükrében (Channel and floodplain development along the Sárköz section of the Danube as reflected by surveys between 1782 and 1950), Földrajzi Értesítö, 23,1, 27-36

Somogyi S., 1979: Regulated rivers in Hungary, Geographica Polonica, 41, 39-53

Szalai Z., 1998: A Duna menti árterek környezeti problémái különös tekintettel a nehézfém terheltségre (Environmental problems of Danubian floodplains with special regard to heavy metal loads), Manuscript. Geographical Research Institute, Centre for Earth Sciences, Hungarian Academy of Sciences, Budapest, 13 p.

Zsuffa I. and László B., 1998: Folyami árterek ökológiai rehabilitációja fokrendszerek segítségével (Ecological rehabilitation of floodplains by way of 'notch' systems), in A vízgazdálkodás ökológiai és természetvédelmi vonatkozásai (Ecological and nature conservation aspects of water management), Hungarian Academy of Sciences, Budapest, $13 \mathrm{p}$.

\section{NOTES}

${ }^{1}$ Research funded by the Hungarian Ministry of the Environment from Targeted Fund for Environmental Protection (KAC, OKTKP-057) and the National Science Foundation (OTKA, K 68903) 
SAŽETAK

\title{
Geomorfološke promjene naplavne ravnice Dunava u Mađarskoj
}

\author{
Dénes Lóczy
}

\begin{abstract}
Nekad prostrane naplavne ravnice Dunava u Mađarskoj dosad su većinom nestale ili su ograničene na neke dijelove rijeke: fluvijalna plavina Szigetköz, manji ostaci u okolici Budimpešte te u području šume Gemenc i Béda-Karapancsa duž najjužnijeg dijela u Mađarskoj, koji se nastavlja i na teritorij Hrvatske (Sl. 1). Naplavne ravnice od davnina predstavljaju vrijedne gospodarske resurse te su upravo stoga i doživjele veliku transformaciju. Danas su uglavnom obrađene i ekološki zaštićene. U ovom je radu dat njihov prirodni razvitak kao i onaj pod utjecajem čovjeka, a vrednovana je i mogućnost njihovog ponovnog oživljavanja. Vrednovana je, dakle, i kartirana fluvijalna topografija naplavne ravnice tj. prirodno i antropogeno preoblikovani oblici kao i današnje fukcioniranje krajolika.
\end{abstract}

EU predlaže da se dosadašnja ekstenzivna antropogena valorizacija, unutar nasipa kontroliranog plavnog područja, smanji ili prekine, te da se ponovo stimulira odgovarajući razvoj prirodnog okoliša. To znači da bi se eksperimentalno, mjestimice, ponovo oživilo tradicionalno gospodarstvo naplavne ravnice (ribolov, ispaša, povrtlarstvo i voćarstvo).

To se već i pokušalo na jednom segmentu naplavne ravnice neposredno uz hrvatsku granicu. Taj dio dunavske naplavne ravnice je od velike ekološke važnosti jer ima funkciju zelenog obalnog koridora. U području Dunavsko-Dravskog nacionalnog parka već je započelo oživljavanje antropogeno oblikovanog reljefa da bi se ponovo oživjela nestala tradicionalna ekonomija naplavne ravnice. Iako tehnički izvediva, obnova starih meandara Dunava u aktivna korita bila bi preskupa. Kako raste vodostaj, kontrola poplava postaje sve ozbiljiniji posao.

Stručnjaci za upravljanje vodenim resursima su shvatili da se naplavne ravnice moraju osposobiti za bolje uskladištavanje plavne vode. Međutim, u neuređenim šumama naplavne ravnice, korov je dosegao takav stupanj rasta da čak zaustavlja prolazak plimnih valova (npr. zimsko grožđe). Djelomična obnova antropogenih kanala (čak izvan granica današnje naplavne ravnice - Zsuffa, I. i Lásló, B. 1998) omogućila bi skladištenje veće količine plavne vode. Postoji i potreba opskrbljivanja ekosustava na naplavnoj ravnici vodom, koji često uključuju rijetke i zaštićene biljke.

Hidrološka, vegetacijska i ekološka istraživanja zajedno s gospodarskim i društvenim istraživanjima te detaljnim proučavanjem prirodnih i antropogenih reljefnih oblika može uvelike pomoći pri donošenju odluka za obnovu naplavne ravnice.

Received (Primljeno): 2007 - 04 - 26

Accepted (Prihvaćeno): 2007 - 10 - 15

\author{
Dénes Lóczy \\ Department of Physical Geography, Institute of \\ Geography, University of Pécs, \\ H-7624 Pécs, Ifjúság útja 6. Hungary \\ Odsjek za fizičku geografiju, Sveučilište u Pečuhu \\ H-7624 Pečuh, Ifjúság útja 6. Hungary
}

